\title{
Alternative Dispute Resolution on Margin Trading Close out at Stock Exchange in India: A Case Study Approach*
}

\section{B. Brahmaiah\#}

Finance \& Accounting, ICFAI Business School (IBS), Hyderabad, India

Email: brahmaiahb@yahoo.com

How to cite this paper: Brahmaiah, B. (2018) Alternative Dispute Resolution on Margin Trading Close out at Stock Exchange in India: A Case Study Approach. Theoretical Economics Letters, 8, 773-779. https://doi.org/10.4236/tel.2018.85053

Received: January 29, 2018

Accepted: March 18, 2018

Published: March 21, 2018

Copyright $\odot 2018$ by author and Scientific Research Publishing Inc. This work is licensed under the Creative Commons Attribution International License (CC BY 4.0).

http://creativecommons.org/licenses/by/4.0/

c) (i) Open Access

\begin{abstract}
The paper examines compliances of the margin trading rules and regulations of the Stock Exchange by trading members while serving their clients in the securities market in India. The paper applies case study approach to study the trading practices of trading members on Indian Stock Exchange systems and identifies the nature of securities market's misuses and abuses. The paper identifies how trading members are violating and avoiding the regulatory compliances. The paper provides inputs for the development of appropriate regulatory framework for prevention of violations of rules and regulations in Indian securities market, prevention of capital market abuses and enables the investor protection. The limitation in a case study approach, the research findings and results may lack generalizability. The results may be generalized in the emerging markets. Hence, researchers are encouraged to study results further in other developed countries. The results provide critical perspectives on regulatory challenges and encourage the regulatory authorities to issue relevant guidelines to stock brokers to prevent from non-compliances of margin trading rules.
\end{abstract}

\section{Keywords}

Alternative Dispute Resolution, Arbitration, Margin Trading, Stock Exchanges, Trading

\footnotetext{
${ }^{\star}$ Names of client (Appellant), trading member, (Respondent), and Exchange were disguised to preserve confidentiality. The facts and circumstances were remained same to maintain originality of the case matter. It was based on an arbitration matter resolved at the leading stock exchange of India. The Arbitration mechanism of the Stock Exchange is framed under the Arbitration and Conciliation Act, 1996 of India.

"Professor.
} 


\section{Introduction}

Northern Investments, an investor aggrieved by the Arbitral Award passed by a Panel of three Arbitrators filed an application to the Appellate Panel Arbitrators of the Stock Exchange, Hyderabad for a claim of INR 74.56 million from Punjab Brokers Pvt Ltd., (Punjab), India [1]. Appellant claimed that the panel of arbitrators passed an award on the basis of doctrine of Estoppel principle and ignored margin trading guidelines. The impugned award lacked the merit and could not attempt to do justice on the principles of natural justice. Northern Investments, a Hyderabad based partnership firm (Appellant), got registered as a client for trading with the Punjab Brokers Pvt Ltd. (Respondent) and had been trading through the Respondent. The Respondent had been extending credit regularly to Appellant and Appellant had been regularizing the position and paying interest on the credit extended to it. Respondent, Punjab Brokers Pvt Ltd., (PB), incorporated under Indian Companies Act, 1956, is a trading member of the Stock Exchange, Mumbai. It is one of the leading stock broking companies in India. The range of services includes broking, investment banking, corporate advisory, and portfolio management services.

\section{Case Description}

The appellant had a position of 48,000 equity shares of Tele Dial with the Respondent on February 12, 2017. The debit balance in the appellant's account stood at INR ${ }^{3} 181.80$ million. As against this debit balance, there was collateral security with the Respondent, consisting of 40,000 shares of Southern Electronics, valued at around INR.75.00 million, and 48,000 shares of Tele Dial which were purchased on credit i.e., liability (debit balance) through the Respondent. The appellant contended that the decision to liquidate the position of the Applicant, by the Respondent was unfair, irregular, and incorrect and mistake. Appellant prayed for reimbursement of its loss of INR 75.00 million.

Appellant had reduced the debit balance from INR 277 million to INR 181 million within three days. Appellant claimed that even after sale of 46,600 shares of Tele Dial, it had collateral value of INR 80.00 million in its account $(40,000$ shares of Southern Electronics @ price of INR 1800, and 1400 shares of Tele Dial @ price of INR 4000). He claimed that Southern Electronics shares were kept as collaterals and these were considered by the Respondent for calculating Margins. The statement of defense submitted by the Respondent also confirmed that Respondent had used Southern Electronics shares for calculating the margins against the Applicant's outstanding debt. It alleged that representatives of Respondent lured Appellant to open account and encouraged it to do speculation in order to earn brokerage on its trading volume and earn interest income on unclear debit balances. He reiterated that the square off was completely unwarranted, and was a grave mistake and gross error on the part of Respondent. Accordingly, Appellant made a claim of INR 75.00 million (INR seventy five million as difference value between the square off price of INR 3920 and appellant's 
sale price of INR 5520 (for 46,600 shares multiplied by INR 1600). Respondent's desperate selling of 46,600 shares itself put a downward pressure on the share price of Tele Dial and caused further fall in the price [2]. Some shares were also traded at INR 3800 and with an average price of INR 3920, as against the 52 week's low price of INR 3750. Owing to sale of these 46,600 shares, the share price of Tele Dial recorded its historical lowest price of INR 3750 as on February 12,2017 , the dates on its shares were liquidated.

Respondent submitted that it complied with all laws, rules, regulations, and circulars governing the relationship between a Trading Member and Client. Despite repeated SMS and oral communications over several days, the Appellant had failed to make full payment towards its liability (debit balance) with them by the respective due dates and had not taken delivery of the shares under reference. Hence, the Respondents had no option other than square off the long position by selling 46,600 shares of Tele Dial. Respondent submitted that it had the discretion to sell the securities including margin available without any notice at any time after $\mathrm{T}+1$ day if the client does not pay dues. In this case, the liquidation was effected on $\mathrm{T}+5$ day from first purchase date and $\mathrm{T}+4$ from second purchase date. The Appellant had ample opportunity to make full payment and take delivery. Respondent submitted that it had consistently alerted the Appellant on the fall in price of the Tele Dial stock and warned about intending liquidation of Tele Dial. Consequent to demand from the Respondent for payment of additional securities margin of INR 30 million to INR 40 million, the Appellant had promised to bring additional cash margin of INR 20 million to the Respondent on February 9, 2017. The Appellant ignored all alerts, warnings and demands raised by the Respondent and grossly failed to provide additional cash or stock margins. The Respondent requested the Appellant to sell stock for at least rupees twenty million which the Appellant flatly refused. Respondent cautioned the Appellant that the trigger price for sale of Tele Dial was fixed at INR 3950 and Risk Department of Respondent would wait till such time where the stock price do not breach below INR 3950. The Appellant was therefore quite aware that once the trigger price was reached, the Respondent would proceed with sale action without any further delay/wait. At the same time, the Appellant defaulted in its promise to bring additional cash margins and refused to bring additional stock margins. The price of the Tele Dial stock fell from INR 5760 on February 5, 2017 to INR 3950 on February 12, 2017. Considering the default situation of the Applicant, it had no locus standi to request the Respondent to wait any longer to dispose the stocks. Respondent disposed off the Tele Dial stock only when the available margins after VaR depleted near to the debit to be recovered (104.80\%). Respondent being a broker earns only brokerage by placing the orders given by the client in the exchange trading platforms. Respondent is not a Bank to arrange funding to the Appellant's positions. Appellant was trying to use the treatment given to it as a goodwill gesture by the respondent and to saddle the losses incurred in the trading account due to the positions created by the Appellant at its free will and volition. 


\section{Discussion and Analysis of Case}

The Panel observed that there were regular debit balances in the Applicant's ledger account and the Appellant would bring the account to credit in a while. It was not a fact that through continuous extension of credit to the Appellant and regular settlement of its dues, the Doctrine of Estoppel had come into play, which prevents the Respondent from taking position not consistent with past practices. The Doctrine of Estoppel ${ }^{1}$ prevents one party from withdrawing a promise made to a second party if the latter has reasonably relied upon that promise. Nature contended that the award passed by the arbitration panel did not take into account the margin trading rules of NSE appropriately while determining the quantum of award. The panel of arbitrators had passed the award on the doctrine of Estoppel ${ }^{1}$ ignoring margin trading guidelines and collaterals. Appellant had derived a level of comfort in its dealings with the Respondent, who had consistently extended credit of substantial value to it and allowed it sufficient time to settle its dues. This had led the Appellant to believe that the Respondent would not precipitate any action when it specifically requested the latter no to do so. Therefore, the action of close out by the Respondent was inconsistent with past practices. The Appellant reported in its personal hearings, that the senior executives of the Respondent have conceded that the decision to liquidate the position was incorrect and have offered to settle the issue with it bilaterally but it could not accept the terms of the settlement as proposed by the Respondent.

As contended by the Respondent that the margin level fell to 104 per cent at the time of liquidation of Tele Dial shares. Respondent liquidated of 46,600 shares of Tele Dial and cleared its full debit balance of INR 182.00 million, ignoring margin calculations and collaterals under custody of Respondent which were owned by the Appellant [3]. When the margin level fell to 104 per cent, Respondent sold blindly more than the required quantity instead of restoring back to comfort level of 120 per cent levels as approved by the Stock Exchange by selling about 28,000 shares. By selling 28,000 shares of Tele Dial for a value of INR 109.48 million at the then prevailing price $(28,000 \times 3920)$, the debit balance would have been reduced to INR 72.6 million from INR 182.00 million. By sale of 28,000 shares, the risk level and situation would have been avoided and margin level would have been restored to an approved level or safety levels of 120 percent after VaR haircut. This would have avoided unwarranted losses to the Appellant. On the contrary, the Respondent ignorantly and hurriedly sold of 46,600 shares and zeroed its debit balance. If there were no collaterals and margins in Appellant's account, Respondent would have been totally correct to clear the full debit balance. Risk Management Department of Respondent ignored to consider holdings of Appellant while liquidating the position of Tele Dial. The Appellate Tribunal came to a conclusion that the close out of 46,600 shares of ${ }^{1}$ Estoppel is a legal principle that prevents a party from denying or alleging a certain factors owing to that party's previous conduct, allegation or denial. The rationale behind estoppel is to prevent injustice owing to inconsistency. 
Tele Dial by the Respondent was not only inconsistent with past practices but also it was grossly wrong and totally mistake of ignoring collaterals and margin of the Appellant. The Appellate Tribunal after analyzing the documents and information furnished by both the parties, found that the Respondent closed the full debit balance instead of selling part of the holdings of Tele Dial to maintain the margin to the level of 120 per cent after the stock Exchange VaR haircut. Respondent argued and contended throughout its defense before earlier original Panel of Arbitrators and the present Panel of Appellate Tribunal that the sale of 46,600 shares of Tele Dial was justified because the margin level came down to 104 per cent, nearer to the 100 per cent of debit balance.

\section{Conclusions}

It is interesting and surprising to note that the Respondent placed two sell orders for 46,600 quantity of shares within less one minute and these were sold within five minutes. These two sell orders have to match with the purchase orders in order to take place trades. It is pertinent to note that there were about 330 purchase orders to meet the two sell orders for 46,600 shares. The shares were sold for price range between INR 4050 to 3790, with an average price of INR 3920. Therefore, Respondent acted in haste and carelessly without considering the fact that the collaterals of Appellant were available with the Respondent. It was concluded the Appellant suffered loss on account of liquidation more shares than the required quantity. The selling 46,600 Tele Dial shares belonging to the Appellant was neither warranted nor desired. Instead of liquidating around 28,000 shares, Respondent liquidated 46,600 shares. Due this sale, Appellant suffered loss on 18,600 shares of Tele Dial. Appellant has right to hold/retain/have shares as per its margin entitlement. Respondent grossly failed to apply margin rules while liquidating the stock of Tele Dial. The loss on sale of extra 18,600 shares of Tele Dial worked out at INR 30.00 million, the price difference of square off price by Respondent and sale price of Appellant on February 22, 2017 (18,600 × 1600 price difference of INR 5520-3910). Appellant sold balance of its 1400 shares of Tele Dial at INR 5510 on February 22, 2017.

It is observed from the statements and submissions that the Respondent's team tried to get some additional funds as margin to safeguard the position of Appellant. Respondent directed and advised the Appellant to bring additional securities margin of INR 30 million to INR 40 million, and the Appellant had promised to transfer cash margin of INR 30 million to the Respondent on February 9, 2017. The Appellant didn't bring either security margin or cash margin. He ignored all alerts, warnings and demands raised by the Respondent. Respondent also requested and advised Appellant to reduce debit balance by selling stock for at least for thirty million so that risky situation could have been avoided. From the submissions, statements and presentations, it is observed that Respondent wanted to come out of the risky situation and avoid losses on account of Appellant's account. Respondent's Dealing Department, Risk Department and others tried to get some funds of INR 30 or 40 million or some addi- 
tional shares as collaterals [4].

It is observed beyond any doubt that the Appellant was allowed to trade heavy volumes on intra days and high debit balances in its account. Respondent used to charge interest on these debit balances. Thus, Respondent earned interest income on these debit balances along with brokerage income. However, Respondent claimed that it is not an NBFC and it is not in the business of lending and earning interest income. But as per statements, Appellant had paid interest on its debit balances. The arrangement was existed and persisted from April 2016 to February 11, 2017. Respondent as well as Appellant accepted, adopted, and practiced the practice of funding till February 11,2017. One can conclude that this arrangement is nothing but margin trading and under this arrangement, Respondent had taken shares of Southern Electronics and other holdings of shares purchased in the market as collaterals to calculate the margin levels and risk management purpose.

\section{Recommendations}

As per the extant rules and regulations of the Stock Exchanges and SEBI, stock margins and cash margins have to be considered while liquidating shares of client in margin trading. Respondent violated the trading rules of Stock Exchange by indulging in liquidating more shares rather than the required quantity to protect the losses of the Respondent. Client had suffered a loss of INR 30.00 million as a result of liquidation. In view of this, the loss on this account has to be borne by the Respondent, on the principles of equity, fairness and natural justice. Investor protection is an important ingredient for the growth and development of the securities markets in any country. The regulatory authorities of the securities markets have to identify and appoint arbitrators in the panel not only from the legal discipline but also experts from the securities market with strong domain knowledge of stock market operations [5]. The arbitrators have to consider and review not only the legal provisions and issues but also trading regulations, trading practices, and marketing techniques of the trading members to attract investors to the securities market. The arbitrators have to analyze the case matter in scientific and systematic way and pass the right, fair, equitable and speaking award on the principles of equity, fairness and natural justice. The results may be generalized in the emerging markets. Hence, researchers are encouraged to study results further in other developed countries.

In view of the foregoing submissions, hearings, documents and arguments of both the parties, and on the bases, its findings and conclusions, the panel of arbitrators set aside the award passed by earlier panel of arbitrators and passed an award that the Respondent was directed to pay an amount of INR 30.00 million (thirty million only) along with an interest of @ 12 percent per annum from the date of this award till payment (for the delayed period) to the Appellant.

\section{References}

[1] SEBI (2017) Circular on Comprehensive Review of Margin Trading Facility, Circu- 
lar No. CIR/MRD/DP/54/2017, 1-8.

[2] SEBI (2010) Arbitration Mechanism in Stock Exchanges. No. CIR/MRD/DSA/29/, 1-4.

[3] (1996) The Arbitration and Conciliation Act. 1-26.

[4] SEBI (2012) Rights and Obligations of Stock Brokers, Sub Brokers and Clients Issued by the SEBI, Mumbai, 1-15.

[5] Brahmaiah, B. (2017) Arbitration on Unauthorized Trades by the Trading Member of the Stock Exchange: An Empirical Study. Theoretical Economics Letters, 7, 1557-1567. https://doi.org/10.4236/tel.2017.76105 